http://dx.doi.org/10.11646/phytotaxa.159.4.1

\title{
A phylogenetic analysis and new delimitation of Crepidiastrum (Asteraceae, tribe Cichorieae)
}

\author{
YU-LAN PENG ${ }^{1,2^{*}}$, YU ZHANG ${ }^{1}$, XIN-FEN GAO ${ }^{1,3^{*}}$, LIN-JING TONG ${ }^{4}$, LIANG LI ${ }^{4}$, REN-YUAN LI $^{4}$, \\ ZHANG-MING ZHU ${ }^{4} \&$ JUN-REN XIAN ${ }^{4}$ \\ ${ }^{1}$ Key Laboratory of Mountain Ecological Restoration and Bioresource Utilization \& Ecological Restoration Biodiversity Conservation \\ Key Laboratory of Sichuan Province, Chengdu Institute of Biology, Chinese Academy of Sciences, P.O. Box 416, Chengdu, Sichuan \\ 610041, China \\ ${ }^{2}$ Email:pengyl@cib.ac.cn \\ ${ }^{3}$ Email:xfgao@cib.ac.cn \\ ${ }^{4}$ Sichuan Agricultural University, Wenjiang, Chengdu, Sichuan 611130, China
}

\begin{abstract}
The systematic position of Paraixeris humifusa (Asteraceae) is hard to define, because the circumscription of Paraixeris, Youngia and Crepidiastrum, three closely related genera in subtribe Crepidinae (Cichorieae), is not clear. This paper reports on the relationships between 30 species in subtribe Crepidinae, based on an analysis of nucleotides from one nuclear (ITS) and three chloroplast DNA regions ( $\operatorname{trn} L-F, \operatorname{rps} 16$ and atpB-rbcL). The phylogenetic analyses used maximum parsimony with maximum likelihood inference. The monophyly of Crepidiastrum in the most recent generic classification of Shih \& Kilian (2011) is explored. The results show that 12 species in Crepidiastrum constitute a monophyletic group, and that Paraixeris humifusa should be treated as Youngia humifusa.
\end{abstract}

\section{Introduction}

The tribe Cichorieae, especially the subtribe Crepidinae and the taxonomically related genera such as Crepidiastrum Nakai (1920: 147) and Youngia Cassini (1831: 88) are difficult groups, because of the weedy nature of some species that are highly polymorphic (Babcock \& Stebbins 1937, Shih 1997, Peng et al. 1998). The generic ranking as well as the evolution of the tribe Cichorieae are not clear, presenting difficult definitional problems. The genus Ixeridium (Gray 1858: 397) Tzvelev (1964: 388) is easily distinguished from Youngia and Crepidiastrum by its slender long-beaked achenes (Pak \& Kawano 1992, Gao 2007). But it has been difficult to distinguish the three genera of Paraixeris Nakai (1920: 155), Youngia and Crepidiastrum through traditional morphology and pollen morphology (Babcock \& Stebbins 1937, Kitamura 1942, Shih 1993, 1997, Gao 2007, Sennikov \& Illarionova 2008, Wang et al. 2009).

The molecular phylogenetic analyses by Enke \& Gemeinholzer (2008) revealed that the Youngia-CrepisIxeridium subclade (including Crepidiastrum ) was one of the two subclades of the Crepidinae clade, consisting predominantly of Eurasian taxa. The fact that the generic limits as well as the evolution of this subclade is always not clear, makes it difficult to understand their relationships through morphology alone. Saito et al. (2006) provided molecular evidence for repeated hybridization events involved in the origin of Crepidiastrum $\times$ nakaii Ohashi \& Ohashi (2007: 339). Four hybrids were described by Ohashi \& Ohashi (2007). A new hybrid Crepidiastrum $\times$ semiauriculatum was reported by Yamamoto et al. (2009: 224). The intergeneric hybridization between Crepidiastrum, Paraixeris or Youngia (Ohashi \& Ohashi 2007, Yano \& Ikeda 2009) make it more difficult to understand the relationships among the three genera and the relationships between species within a particular genus. 


\section{Acknowledgments}

We thank Mr Qiang Liu, Sichuan Agriculture University, for his help in laboratory work. We also thank Mr Lu Peng, Sichuan University, for his help in the collection of field material. We thank Mr Jian Gu for providing the line drawing of Paraixeris humifusa. We thank Professor Libing Zhang for his help in revising this manuscript. This study was supported by National Natural Science Foundation for Young Scholars (Grant No. 31000096), Knowledge innovation project of Chinese Academy of Sciences (Grant No.Y1B2041100), 12th Five-year Plan Project of the National Science and Technology of China (Grant No. 2011BAC09B04-04-02), Sichuan Province Science and Technology Project (No. 2013NZ0037). We would also like to thank anonymous reviewers and editor Alexander Sennikov for carefully reviewing our manuscript and providing constructive comments.

\section{References}

Baldwin, B.G. (1992) Phylogenetic utility of the internal transcribed spacers of nuclear ribosomal DNA in plants: An example from the Compositae. Molecular Phylogenetics and Evolution 1: 3-16. http://dx.doi.org/10.1016/1055-7903(92)90030-k

Babcock, E.B. \& Stebbins, G.L. (1937) The genus Youngia. Carnegie Institution of Washington publication 484: 1-106.

Clevinger, J.A. \& Panero, J.L. (2000) Phylogenetic analysis of Silphium and subtribe Engelmanniinae (Asteraceae: Heliantheae) based on ITS and ETS sequence data. American Journal of Botany 87: 565-572. http://dx.doi.org/10.2307/2656600

Czerepanov, S.K. (1964) Youngia. In: Bobrov, E.G. \& Tzvelev, N.N. (eds.) Flora of the USSR 29. Academy of Sciences of the USSR, Moscow \& Leningrad, pp. 385-387.

Cassini, H. de (1831) Descriptions de quelques Synanthérées de l'île Maurice. Annales des Sciences Naturelles (ser. 1) 23: 8493.

Dunn, S.T. \& Wright, C.H. (1903) Descriptions of New Chinese Plants. Journal of the Linnean Society, Botany 35: $483-518$. http://dx.doi.org/10.1111/j.1095-8339.1903.tb00699.x

Enke, N. \& Gemeinholzer, B. (2008) Babcock revisited: new insights into generic delimitation and character evolution in Crepis L. (Compositae: Cichorieae) from ITS and matK sequence data. Taxon 57: 756-768.

Francisco-Ortega, J., Seon-Joo, P., Santos-Guerra, A., Benabid, A. \& Jansen, R.K. (2001) Origin and evolution of the endemic Macaronesian Inuleae (Asteraceae): Evidence from the internal transcribed spacers of nuclear ribosomal DNA. Biological Journal of the Linnaean Society 72: 77-97. http://dx.doi.org/10.1111/j.1095-8312.2001.tb01302.x

Gao, Z.-L. (2007) Study on the Subtribe Lactucinae of Compositae from Shandong. Master degree dissertation. Shandong Normal University.

Gray, A. (1859) Diagnostic characters of new species of phaenogamous Plants, Collected in Japan by Charles Wright, botanist of the U. S. North Pacific Exploring Expedition with observations upon the relations of the Japanese Flora to that of North America, and of other parts of the Northern Temperate Zone. Memoirs of the American Academy of Arts and Science (new series) 6, Part II: $377-452$. http://dx.doi.org/10.2307/25057953

Hall, T. (2007) BioEdit: Biological sequence alignment editor for Win 95/98/NT/2K/XP [Online]. Website last modified on June 27, 2007.

Handel-Mazzetti (1938) Plantae Sinenses. Acta Horti Gothoburgensis 12(9): 353.

ICN (Hand, R., Kilian, N. \& Raab-Straube, E. von; general editors) (2009-, continuously updated) International Cichorieae Network: Cichorieae Portal. Published on the Internet at http://wp6-cichorieae.e-taxonomy.eu/portal/; accessed [June 20, 2013].

Kitamura, S. (1942) Expositiones plantarum novarum orientali-Asiaticarum VII. Acta Phytotaxonomica et Geobotanica 11: $120-133$.

Kilian, N., Gemeinholzer, B. \& Lack, H.W. (2009) Cichorieae. In: Funk, V.A., Susanna, A., Stuessy, T.F., Bayer, R.J. (eds.) Systematics, Evolution and Biogeography of Compositae. International Association for Plant Taxonomy, Vienna, Austria, pp. 343-383.

Kitagawa, M. (1937) Some plants from Inner Mongolia collected by Mr. T. Akagi in the year 1936. Journal of Japanese Botany 13(6): 425-434.

Kim, K.J., Choi, K.S. \& Jansen, R.K. (2005) Two chloroplast DNA inversions originated simultaneously during the early evolution of the sunflower family (Asteraceae). Molecular Biology and Evolution 22: 1783-1792. http://dx.doi.org/10.1093/molbev/msi174

Kim, S.C. \& Crawford, D.J. (1996) Phylogenetic relationships among the genera of the subtribe Sonchinae (Asteraceae): Evidence from ITS sequences. Systematic Botany 21: 417- 432.

http://dx.doi.org/10.2307/2419668 
Lack, H.W. (2006) Tribe Cichorieae Lam. \& DC. In: Kadereit J. W. \& Jeffrey C. (eds.) Kubitzki's The families and genera of vascular plants 8 . Springer, Berlin, pp. 180-199.

Ledebour, C.F. (1846) Flora Rossica 2(2, 7). E. Schweizerbart, Stuttgart, pp. 719-937.

Léveillé, H. (1913) Decades plantarum novarum. Repertorium Specierum Novarum Regni Vegetabilis 12: 127-131. http://dx.doi.org/10.1002/fedr.4870122206

Liu, J.-Q., Gao, T.-G., Chen, Z.-D. \& Lu, A.-M. (2002) Molecular phylogeny and biogeography of the Qinghai-Tibet Plateau endemic Nannoglottis (Asteraceae). Molecular Phylogenetics and Evolution 23: 307-325. http://dx.doi.org/10.1016/s1055-7903(02)00039-8

Miller, M.A., Pfeiffer,W. \& Schwartz, T. (2010) Creating the CIPRES Science Gateway for inference of large phylogenetic trees. In: Institute of Electrical and Electronics Engineers (eds.) Proceedings of the Gateway Computing Environments Workshop (GCE), 14 Nov. 2010. New Orleans, LA, pp. 1-8. http://dx.doi.org/10.1109/gce.2010.5676129

Nakamura, K., Chung, K.-F., Huang, C.-J., Kokubugata, G.Y.K. \& Peng, C.-I. (2012) Extreme habitats that emerged in the Pleistocene triggered divergence of weedy Youngia (Asteraceae) in Taiwan. Molecular Phylogenetics and Evolution 63: 486-499. http://dx.doi.org/10.1016/j.ympev.2012.01.023

Nakai, T. (1920) Notulae ad plantas Japoniae et Koreae, XXIII. Botanical Magazine (Tokyo) 34: 142-159.

Ohashi, H. \& Ohashi, K. (2007) Hybrids in Crepidiastrum (Asteraceae). Journal of Japanese Botany 82(6): 339-342.

Oxelman, B., Liden, M. \& Berglund, S. (1997) Chloroplast rps16 intron phylogeny of the tribe Sileneae (Caryophyllaceae). Plant Systematics and Evolution 206: 393-410. http://dx.doi.org/10.1007/bf00987959

Pak, J.H. \& Kawano, S. (1990) Biosystematic studies on the genus Ixeris and its allied genera (Compositae-Lactuceae) III. Fruit wall anatomy and karyology of Crepidiastrum and Paraixeris, and their taxonomic implications. Acta Phytotaxonomica Geobotanica 41: 109-128.

Pak, J.H. \& Kawano, S. (1992) Biosystematic studies on the genus Ixeris and its allied genera (Compositae: Lactuceae) 4. Taxonomic treatments and nomenclature. Memoirs of the Faculty of Science Kyoto University, Series of Biology 15: 2961.

Pak, J.H. \& Bremer, K. (1995) Phylogeny and reclassification of the genus Lapsana (Asteraceae: Lactuceae). Taxon 44: 13-21. http://dx.doi.org/10.2307/1222673

Peng, C.-I., Chung, K.-F. \& Li, H.-L. (1998) Compositae. In: Editorial Committee of the Flora of Taiwan (eds.) Flora of Taiwan, ed. 2, vol. 4. Editorial Committee of the Flora of Taiwan, Taipei, Republic of China, pp. 807-1101.

Small, R.L., Ryburn, J.A., Cronn, R.C., Seelanan, T. \& Wendel, J.F. (1998) The tortoise and the hare: choosing between noncoding plastome and nuclear Adh sequences for phylogeny reconstruction in a recently diverged plant group. American Journal of Botany 85: 1301-1315. http://dx.doi.org/10.2307/2446640

Sang, T., Crawford, D.J., Kim, S.C. \& Stuessy, T.F. (1994) Radiation of the endemic genus Dendroseris (Asteraceae) on the Juan Fernandez Islands: Evidence from sequences of the ITS regions of nuclear ribosomal DNA. American Journal of Botany 81: 1494-1501. http://dx.doi.org/10.2307/2445322

Sang, T., Crawford, D.J., Kim, S.C., Stuessy, T.F. \& Silva, M.O. (1995) ITS sequences and the phylogeny of the genus Robinsonia (Asteraceae). Systematic Botany 20: 55-64. http://dx.doi.org/10.2307/2419632

Saito, Y., Moller, M., Kokubugata, G., Katsuyamat, T., \& Iwashina, T. (2006) Molecular evidence for repeated hybridization events involved in the origin of the genus Crepidiastrixeris (Asteraceae) using RAPDs and ITS data. Botanical Journal of the Linnaean Society 151: 333-343. http://dx.doi.org/10.1111/j.1095-8339.2006.00513.x

Shih, C. (1993) On the classification of Ixeris group (Compositae) from China. Acta Phytotaxomica Sinica 31(6): 533-548.

Shih, C. (1997) Compositae (10). In: Ling, Y. \& Shih, C. (eds.) Flora Reipublicae Popularis Sinicae 80(1). Science Press, Beijing, pp. 106-266. http://dx.doi.org/10.2307/4111053

Shih, C. \& Kilian, N. (2011) Crepidiastrum. In: Wu, Z.-Y., Raven, P.H. \& Hong, D.-Y. (eds.) Flora of China 20-21. Science Press, Beijing \& Missouri Botanical Garden Press, St. Louis, pp. 264-269. http://dx.doi.org/10.1663/0013-0001(2007)61[101b:focvp]2.0.co;2

Swofford, D.L. (2002) PAUP*: Phylogenetic analysis using parsimony (*and other methods), version 4.0b10. Sunderland, Massachusetts: Sinauer.

Sennikov, A.N. \& Illarionova, I.D. (2008) Generic delimitation of the subtribe Ixeridinae newly segregated from Crepidiinae (Asteraceae-Lactuceae). Komarovia 5: 57-115.

Sennikov, A.N. (1997) Critical notes on the species of the subtribes Lactucinae and Crepidinae (Asteraceae, Lactuceae) from Mongolia, China and Vietnam. Botanicheskii Zhurnal (Moscow \& Leningrad) 82(5): 110-117.

Sprengel, C. (1826) Systema vegetabilium (ed. 16) 3. Sumptibus Librariae Dieterichianae, Göttingen, 936 pp. http://dx.doi.org/10.5962/bhl.title.822 
Stebbins, G. L. (1937) Critical notes on the genus Ixeris. The Journal of Botany, British and Foreign 75: 43-51.

Taberlet, P., Gielly, L., Pautou, G. \& Bouvet, J. (1991) Universal primers for amplification of three non-coding regions of chloroplast DNA. Plant Molecular Biology 17: 1105-1109. http://dx.doi.org/10.1007/bf00037152

Tzvelev, N.N. (1964) Ixeridium (A. Gray) Tzvel. In: Bobrov, E.G. \& Tzvelev, N.N. (eds.) Flora of the USSR 29. Academy of Sciences of the USSR, Moscow \& Leningrad, pp. 388-393.

Wang, H., Wortley, A.H. \& Blackmore, S. (2009) Pollen morphology of Crepidinae and Lactucinae (Asteraceae: Cichorieae) and its systematic significance. Grana 48: 160-178. http://dx.doi.org/10.1080/00173130902931209

Wang, Y.-J., Liu, J.-Q. \& Miehe, G. (2007) Phylogenetic origins of the Himalayan endemic Dolomiaea, Diplazoptilon and Xanthopappus (Asteraceae: Cardueae) based on three DNA regions. Annals of Botany 99: 311-322.

Walpers, W. P. (1846) Repertorium Botanices Systematicae 6(2). F. Hofmeister, Leipzig, 193-384 pp. http://dx.doi.org/10.5962/bhl.title. 7553

Whitton, J., Wallace, R.S. \& Jansen, R.K. (1995) Phylogenetic relationships and patterns of character change in the tribe Lactuceae (Asteraceae) based on chloroplast DNA restriction site variation. Canadian Journal of Botany 73: 1058-1073. http://dx.doi.org/10.1139/b95-115

Willdenow, C.L. von (1803) Species Plantarum (ed. 4) 3(3). G.C. Nauk, Berlin, pp. 1477-2409.

Zhang, J.-W., Nie, Z.-L., Wen, J. \& Sun, H. (2011) Molecular phylogeny and biogeography of three closely related genera, Soroseris, Stebbinsia and Syncalathium (Asteraceae, Cichorieae), endemic to the Tibetan Plateau, SW China. Taxon 60: 15-26.

Zhao, Y.-Z. \& Ma, L. (2003) A new species of Youngia (Compositae) from China. Bulletin of Botanical Research 23(3): 261262.

Zhao, Y.-Z. \& Ma, L. (2004) A new species of Youngia (Compositae) from China. Bulletin of Botanical Research 24(2): 133134.

Yamamoto, N., Yano, O. \& Ikeda, H. (2009) A new hybrid, Crepidiastrum $\times$ semiauriculatum (Asteraceae: Lactuceae), from Okayama Prefecture, Western Japan. Journal of Japanese Botany 84: 224-228. 